\title{
Linear sweep voltammetric determination of free chlorine in waters using graphite working electrodes
}

\author{
K.A.S. Pathiratne , S.S. Skandaraja and E.M.C.M. Jayasena \\ Department of Chemistry, Faculty of Science, University of Kelaniya, Kelaniya.
}

Revised: 16 June 2007 ; Accepted: 23 July 2007

\begin{abstract}
Applicability of linear sweep voltammetry using graphite working electrodes for determination of free chlorine in waters was demonstrated. Influence of the nature of supporting electrolyte, its concentrations, $\mathrm{pH}$ and rate of potential variation of working electrode on voltammetric responses corresponding to the oxidation of $\mathrm{ClO}^{-}$were examined. It was found that, any of the salt solutions $\mathrm{KNO}_{3}, \mathrm{~K}_{2} \mathrm{SO}_{4}$ or $\mathrm{Na}_{2} \mathrm{SO}_{4}$ at the optimum concentration of $0.1 \mathrm{~mol} \mathrm{dm}^{-3}$ could be used as a supporting electrolyte for the above determination. The study also revealed that, any $\mathrm{pH}$ in the range of 8.5 to 11 could yield satisfactory results. The anodic peak current at the working electrode potential of $+1.030 \mathrm{~V} \mathrm{vs} \mathrm{Ag/AgCl} \mathrm{reference} \mathrm{electrode} \mathrm{was} \mathrm{found}$ to linearly increase with concentration of free chlorine up to $300 \mathrm{mg} \mathrm{dm}^{-3}\left(\mathrm{R}^{2}=0.9996\right)$. The results indicated that the anodic peak current could be used as the basis for a simple, rapid and accurate determination of $\mathrm{ClO}^{-}$in waters in the concentration range from $1.0 \mathrm{mg} \mathrm{dm}^{-3}$ to $300.0 \mathrm{mg} \mathrm{dm}^{-3}$ with a high degree of reproducibility ( $\%$ RSD $<1.5$ ). The results obtained with the proposed method for determination of concentrations of $\mathrm{ClO}^{-}$in commercial bleaching agents were in good agreement with those determined iodometrically $(\%$ difference $<1.5)$. The method proved advantageous as it does not require purging of test solutions with nitrogen for removing of dissolved oxygen prior to voltammetric determinations. The applicability of square wave voltammetry in place of linear sweep voltammetry for determination of $\mathrm{ClO}^{-}$has also been demonstrated.
\end{abstract}

Keywords: Free chlorine, graphite working electrodes, linear sweep voltammetry

\section{INTRODUCTION}

Hypochlorite is a powerful oxidizing agent and it is used for various purposes such as disinfection, bleaching and manufacturing processes ${ }^{1-4}$. It is an efficient and inexpensive oxidant and is available as sodium hypochlorite in alkaline solutions, with a $\mathrm{pH}$ of approximately 11 . It can be easily synthesized, handled and stored. During disinfecting processes, it is added to potable waters and it undergoes hydrolysis in water forming hypochlorous acid and hypochlorous ions.

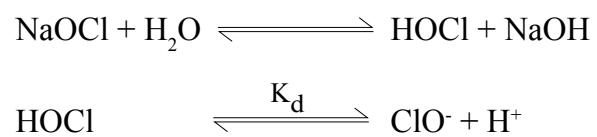

(Dissociation Constant, $\mathrm{K}_{\mathrm{d}}=2.9 \times 10^{-8} \mathrm{~mol} \mathrm{dm}^{-3}$ )

As shown by equation (2), hypochlorous acid undergoes further dissociation and depending on the $\mathrm{pH}$, concentrations of the two species, $\mathrm{HOCl}$ and $\mathrm{ClO}^{-}$, may vary. At $\mathrm{pH}>8.5, \mathrm{ClO}^{-}$is the dominant species and at $\mathrm{pH}<5.5, \mathrm{HOCl}$ is the dominant species.

Free chlorine is defined as the residual chlorine present as dissolved gas $\left(\mathrm{Cl}_{2}\right)$, hypochlorous acid (HOCI) and the hypochlorous anion. $\left(\mathrm{ClO}^{-}\right)$in water bodies due to excessive usage of sodium hypochlorite during disinfection of water bodies. The three forms of chlorine exist together in equilibrium in water and their relative proportions are determined by $\mathrm{pH}$ and the temperature of the water. At the $\mathrm{pH}$ of 10 used in the present investigation free chlorine exists almost $100 \%$ as $\mathrm{ClO}^{-}$. High concentrations of chlorine in drinking water can result in odour and taste. Currently there are growing concerns on the hazardous effects of free chlorine in water at higher concentrations.

Several analytical methods such as iodometry and spectrophotometry are currently used to estimate $\mathrm{ClO}^{-}$ concentration in waters ${ }^{5}$. None of these methods is ideal for convenient and rapid determination of free chlorine. An electro-analytical technique for determination of free chlorine $^{6-9}$ is very attractive as it does not require special 
analytical reagents and can be conveniently employed in waters for online monitoring of $\mathrm{ClO}^{-}$.

The two reduction reactions given below has been used in the past for determination of $\mathrm{ClO}^{-}$in water electrochemically.

$$
\begin{aligned}
& \mathrm{ClO}^{-}+\mathrm{H}_{2} \mathrm{O}+2 \mathrm{e} \rightleftharpoons \mathrm{Cl}^{-}+2 \mathrm{OH}^{-} \\
& \mathrm{HClO}+2 \mathrm{e} \rightleftharpoons \mathrm{Cl}^{-}+\mathrm{OH}^{-}
\end{aligned}
$$

Use of these reactions have been found inconvenient as the reduction of dissolved $\mathrm{O}_{2}$ in water occurs around the same potential region [equations (6) \& (7) $]^{10}$.

$$
\begin{array}{ll}
\mathrm{O}_{2}+4 \mathrm{H}^{+}+4 \mathrm{e} \rightleftharpoons 2 \mathrm{H}_{2} \mathrm{O} & \mathrm{E}^{\mathrm{o}}=+1.229 \mathrm{~V} \\
\mathrm{O}_{2}+2 \mathrm{H}^{+}+4 \mathrm{e} \rightleftharpoons \mathrm{H}_{2} \mathrm{O}_{2} & \mathrm{E}^{\mathrm{o}}=+0.682 \mathrm{~V}
\end{array}
$$

Two oxidation reactions [equations (8) \& (9) $]^{6}$ have also been used successfully for determination of free chlorine in water.

$$
\begin{aligned}
& 6 \mathrm{ClO}^{-}+3 \mathrm{H}_{2} \mathrm{O} \rightleftharpoons 2 \mathrm{ClO}_{3}^{-}+4 \mathrm{Cl}^{-}+6 \mathrm{H}^{+}+3 / 2 \mathrm{O}_{2}+6 \mathrm{e} \\
& 6 \mathrm{HClO}+3 \mathrm{H}_{2} \mathrm{O} \rightleftharpoons 2 \mathrm{ClO}_{3}^{-}+4 \mathrm{Cl}^{-}+12 \mathrm{H}^{+}+3 / 2 \mathrm{O}_{2}+6 \mathrm{e}
\end{aligned}
$$

With this method, interference of dissolved $\mathrm{O}_{2}$ does not occur as oxidation potential of $\mathrm{ClO}^{-}$is well separated from the oxidation/reduction potential of dissolved oxygen. However, the method requires a relatively expensive supporting electrolyte, $\mathrm{NaClO}_{4}$ and a working electrode (platinum, gold or glassy carbon) ${ }^{6}$. Further, the limit of detection of the method was relatively high $\left(4 \mathrm{mg} \mathrm{dm}^{-3}\right)$. The method reported in this study uses less expensive supporting electrolytes $\left(\mathrm{KNO}_{3}\right.$ or $\mathrm{K}_{2} \mathrm{SO}_{4}$ or $\mathrm{Na}_{2} \mathrm{SO}_{4}$ ) together with an inexpensive graphite working electrode. Further, a lower limit of detection of $1.0 \mathrm{mg}$ $\mathrm{dm}^{-3}$ and higher linear range up to $300 \mathrm{mg} \mathrm{dm}^{-3}$ were achieved with the proposed method.

\section{METHODS AND MATERIALS}

Reagents, chemicals and instrumentation: Sodium hypochlorite required was synthesized using analytical grade $\mathrm{NaOH}, \mathrm{KMnO}_{4}$ and $\mathrm{HCl}$ supplied from Fluka. The salts $\mathrm{KNO}_{3}, \mathrm{~K}_{2} \mathrm{SO}_{4}$ and $\mathrm{Na}_{2} \mathrm{SO}_{4}$ used were also of analytical grade supplied from Fluka. Double distilled and de-ionized water was prepared using an all glass distiller and a Barnstead deionizer at the resistivity $18 \mathrm{~m} \Omega \mathrm{cm}$. $\mathrm{pH}$ of the solutions were measured using an Orion model $294 \mathrm{pH}$ meter and its electrodes. All glassware were soaked overnight in $5 \% \mathrm{HNO}_{3}$ acid solution and carefully cleaned with distilled and deionized water. They were air dried in a dust free environment prior to use. $\mathrm{NaOCl}$ was prepared by oxidizing $\mathrm{HCl}$ with $\mathrm{KMnO}_{4}$ and passing the resultant gas into $\mathrm{NaOH}$ solution. Hypochlorite concentration of the resultant solution was determined by iodometric titration ${ }^{5}$. This solution was used as the stock $\mathrm{NaOCl}$ solution for the present investigation.

EG \& G Princeton Applied Research Model 394 Electrochemical Trace Analyzer equipped with a three electrode cell was used for the present investigation. A graphite disk electrode ( $3 \mathrm{~mm}$ in diameter) was used as the working electrode, a platinum wire $(2 \mathrm{~mm}$ in diameter) and $\mathrm{Ag} / \mathrm{AgCl}$ reference electrode (Princeton Applied Research) were used as counter and reference electrodes respectively. All potentials were reported with respect to the $\mathrm{Ag} / \mathrm{AgCL}$ reference electrode.

Pretreatment of graphite working electrodes: The surface of the working electrode was polished initially with $0.3 \mu \mathrm{m}$ alumina slurry followed by $0.05 \mu \mathrm{m}$ alumina slurry, carefully sonicated in de-ionized water for few minutes and then rinsed with de-ionized water. The polished electrode was pretreated in an electrolytic solution, which was used for the investigation, by scanning the working electrode potential in the range of $-0.800 \mathrm{~V}$ to $+1.200 \mathrm{~V}$.

Study of the dependence of voltammetric response on experimental variables: Dependence of the voltammetric response on the experimental parameters: deaeration, $\mathrm{pH}$ of solution, type of supporting electrolyte, concentration of supporting electrolyte, rate of scanning of working electrode potential and concentration of free chlorine were examined. Performance of the method was compared with that of square wave voltammetry. Results obtained with the proposed method under optimum conditions were evaluated with those obtained by the conventional iodometric method.

\section{RESULTS}

\section{Voltammetric response and its dependence on purging with $\mathbf{N}_{2}$}

Figure 01 shows the voltammograms obtained for the oxidation of $\mathrm{ClO}^{-}$at a concentration of $50 \mathrm{mg} \mathrm{dm}^{-3}$ in $0.1 \mathrm{~mol} \mathrm{dm}^{-3} \mathrm{KNO}_{3}$ solution. The potential of the working electrode was scanned at a rate of $50 \mathrm{mVs}^{-1}$ from an initial potential value of $-0.800 \mathrm{~V}$ to a final potential value of $+1.200 \mathrm{~V}$. The $\mathrm{pH}$ of the solution was 10.0. The shape of the voltammogram in Figure 01(a) obtained after purging about $25 \mathrm{~cm}^{3}$ analyte solution with $\mathrm{N}_{2}$ at an input pressure of $\sim 5$ psi for $15 \mathrm{~min}$ and blanketing the solution with a flow of $\mathrm{N}_{2}$ gas is identical to the voltammogram in Figure 01(b) obtained with no purging of the analyte solution with $\mathrm{N}_{2}$ prior to analysis. 

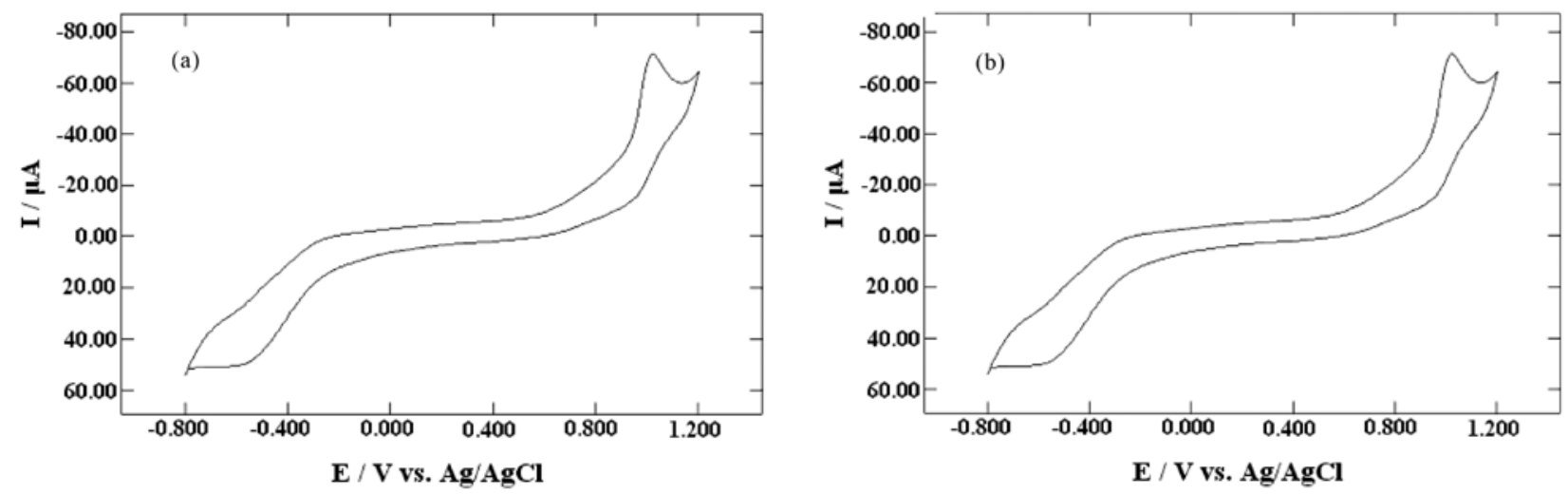

Figure 1: Cyclic voltammograms for a CIO- concentration of $50 \mathrm{mg} \mathrm{dm}^{-3}$ in $0.10 \mathrm{~mol} \mathrm{dm}^{-3} \mathrm{KNO}_{3}$ solution obtained with graphite electrode (a) purging with nitrogen for $15 \mathrm{~min}$. (b) with no nitrogen purging. Initial and final potentials were $-0.800 \mathrm{~V}$ and $+1.200 \mathrm{~V}$ respectively. Scan rate was $50 \mathrm{mV} \mathrm{s}^{-1}$ and the $\mathrm{pH}$ of the solution was 10.0 .

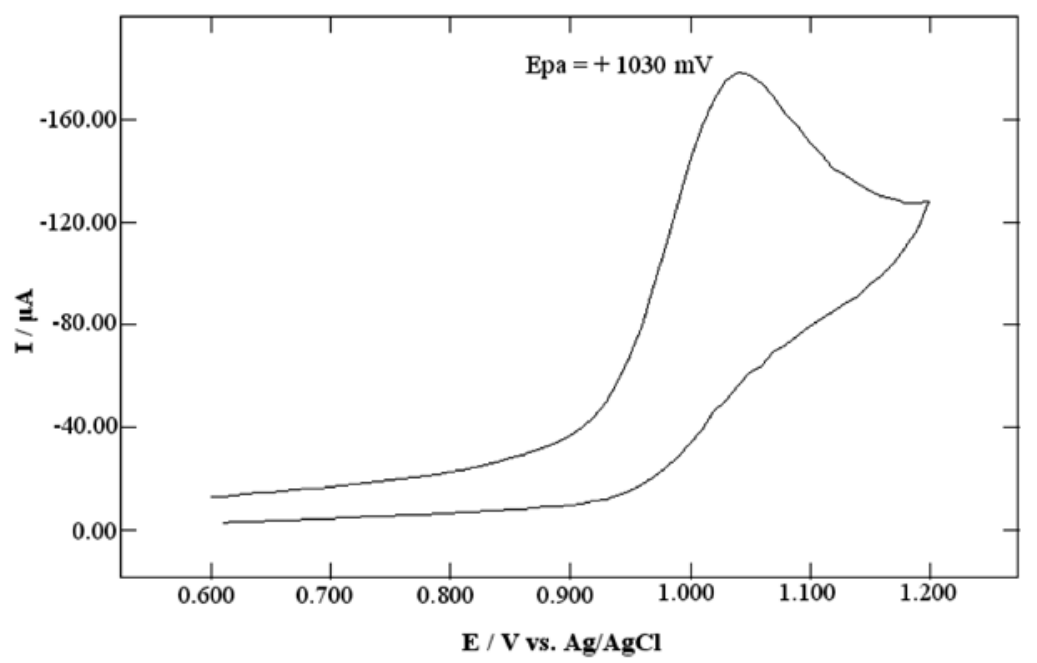

Figure 2: Cyclic voltammogram for a $\mathrm{CIO}^{-}$concentration of $150 \mathrm{mg} \mathrm{dm}^{-3}$ in $0.10 \mathrm{~mol} \mathrm{dm}^{-3} \mathrm{KNO}_{3}$ solution obtained with the graphite electrode. Initial and final potentials were $+0.600 \mathrm{~V}$ and $+1.200 \mathrm{~V}$ respectively. Scan rate was $50 \mathrm{mV} \mathrm{s}^{-1}$ and $\mathrm{pH}$ of the solution was 10.0.

Peak current $(70.90 \mu \mathrm{A})$ and peak potential $(+1.030 \mathrm{~V})$ corresponding to the oxidation of $\mathrm{ClO}^{-}$remain the same in the two voltammograms. Since the presence or absence of oxygen has no effect on the analytical peak at $+1.030 \mathrm{~V}$ vs $\mathrm{Ag} / \mathrm{AgCl}$ reference electrode, no oxygen removal is required for determination of free chlorine by the proposed method.

Figure 02 shows a voltammogram obtained for a solution containing $150 \mathrm{mg} \mathrm{dm}^{-3} \mathrm{CLO}^{-}$in $0.10 \mathrm{~mol} \mathrm{dm}^{-3}$ $\mathrm{KNO}_{3}$ solution at $\mathrm{pH}=10.0$. The solution was not purged with $\mathrm{N}_{2}$ before analysis. The potential was scanned from $+0.600 \mathrm{~V}$ to a final potential of $+1.200 \mathrm{~V} \mathrm{Vs} \mathrm{Ag/AgCl}$ reference electrode, at a scan rate of $50 \mathrm{mV} \mathrm{s}^{-1}$. The voltammogram clearly shows that voltammetric response corresponding to oxidation of $\mathrm{ClO}^{-}$can be measured without purging with $\mathrm{N}_{2}$. The scan range of $+0.600 \mathrm{~V}$ and $+1.200 \mathrm{~V}$ vs $\mathrm{Ag} / \mathrm{AgCl}$ reference electrode could be used for the analysis of $\mathrm{ClO}^{-}$.

\section{Effect of solution pH on voltammetric response}

Figure 03 shows the linear sweep voltammograms obtained for solutions at $\mathrm{pH} 1.0,2.0,4.0,6.0,8.0,10.0$, 11.0 and 12.0. The concentration of $\mathrm{ClO}^{-}$in each solution was $50 \mathrm{mg} \mathrm{dm}^{-3}$. The potential of the working electrode was scanned from $+0.600 \mathrm{~V}$ to $+1.200 \mathrm{~V}$ at a rate of $50 \mathrm{mV} \mathrm{s}^{-1}$. No peak was observed at $\mathrm{pH}$ less than 2 as at low $\mathrm{pHs}$ the concentrations of $\mathrm{ClO}^{-}$is negligible. With increasing $\mathrm{pH}$ up to nearly 11.0 , the signal has continuously increased as $\mathrm{ClO}^{-}$concentration in the medium increased with decreasing $\mathrm{H}^{+}$concentration. For the present analysis, $\mathrm{pH}$ of 10.0 was taken as the optimum $\mathrm{pH}$ of the solution. 


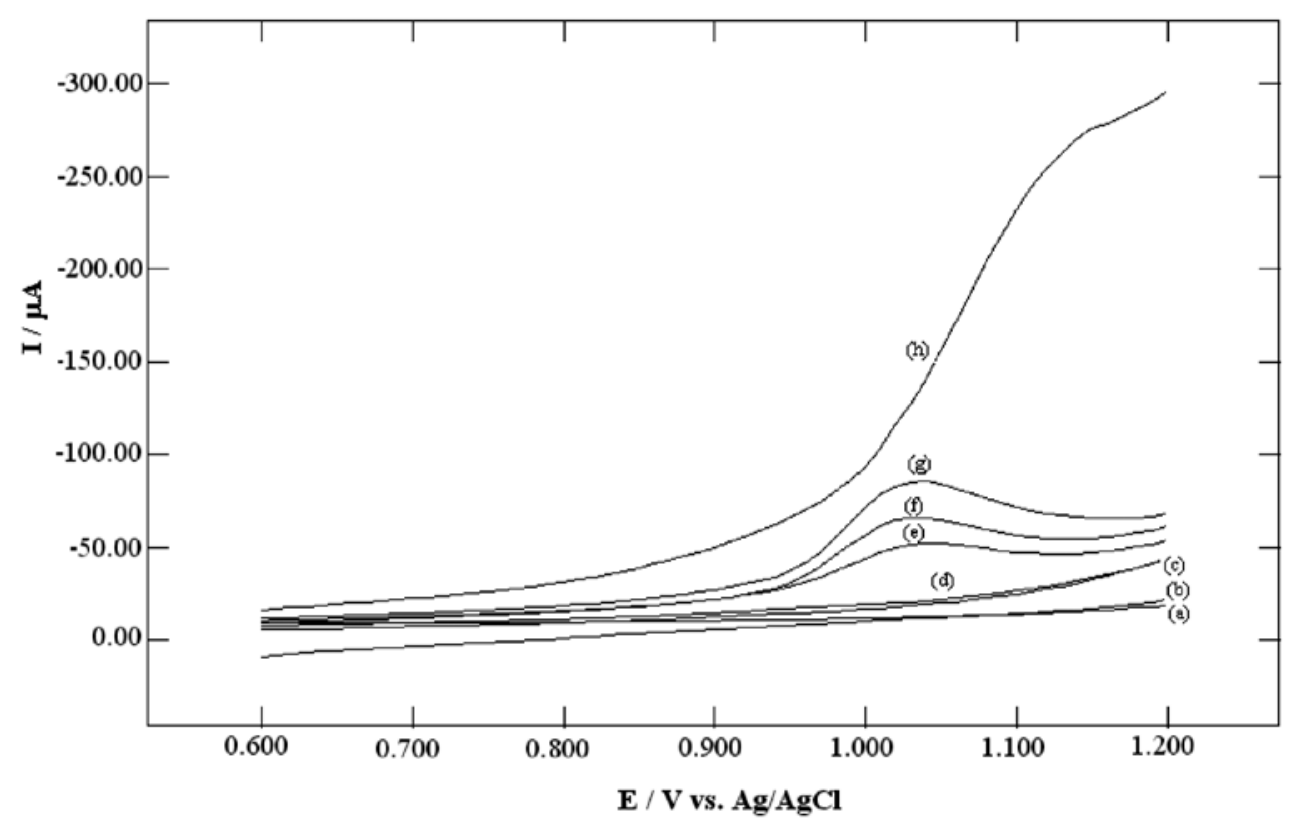

Figure 3: Linear sweep voltammograms at several different $\mathrm{pH}$ of analyte solution (a) 1.0, (b) 2.0, (c) 4.0, (d) 6.0, (e) 8.0 , (f) 10.0 , (g) 11.0 and (h) 12.0 for a free chlorine concentration of $50 \mathrm{mg} \mathrm{dm}^{-3}$ in $0.10 \mathrm{~mol} \mathrm{dm}^{-3} \mathrm{KNO}_{3}$ supporting electrolyte for a graphite working electrode. Initial and final potentials were $+0.600 \mathrm{~V}$ and $+1.200 \mathrm{~V}$ respectively.

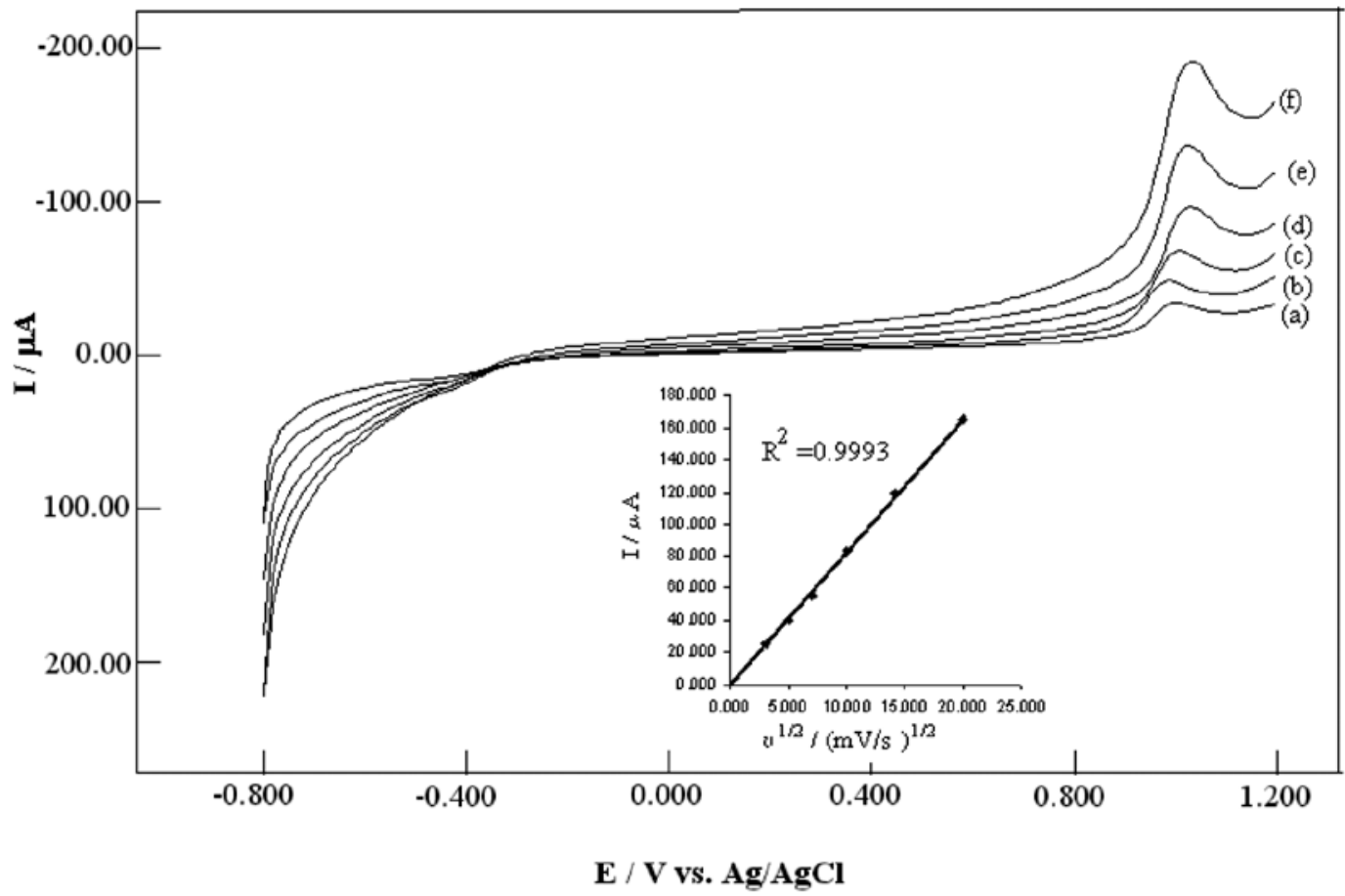

Figure 4: Linear sweep voltammograms for a $\mathrm{CIO}^{-}$concentration of $50 \mathrm{mg} \mathrm{dm}^{-3}$ in $0.1 \mathrm{~mol} \mathrm{dm}^{-3} \mathrm{KNO}_{3}$ supporting electrolyte with the graphite electrode. Initial and final potentials were $-0.800 \mathrm{~V}$ and $+1.200 \mathrm{~V}$ respectively. Scan rates were: (a) $10 \mathrm{mV} \mathrm{s}^{-1}$, (b) $25 \mathrm{mV} \mathrm{s}^{-1}$, (c) $50 \mathrm{mV} \mathrm{s}^{-1}$, (d) $100 \mathrm{mV} \mathrm{s}^{-1}$, (e) $250 \mathrm{mV} \mathrm{s}^{-1}$, (f) $400 \mathrm{mV} \mathrm{s}^{-1}$. Insert shows the Randle Sevcik plot of anodic peak current against the square root of the sweep rate. 
Table1 1: The effect of type of supporting electrolyte and its concentration on the peak potential and the peak current. (Free chlorine concentration was $50 \mathrm{mg} \mathrm{dm}{ }^{-3}$ in $0.1 \mathrm{~mol} \mathrm{dm}^{-3} \mathrm{KNO}_{3}$ supporting electrolyte. The working electrode was graphite. Initial and final potentials were $-0.800 \mathrm{~V}$ and $+1.200 \mathrm{~V}$ respectively and scan rates was $50 \mathrm{mV} \mathrm{s}^{-1}$ ).

\begin{tabular}{|c|c|c|c|}
\hline Electrolyte & $\begin{array}{l}\text { Concentration of } \\
\left.\text { electrolyte } /(\mathrm{mol} \mathrm{dm})^{-3}\right)\end{array}$ & Peak potential / V & Peak current $/ \mu \mathrm{A}$ \\
\hline $\mathrm{KNO}_{3}$ & 0.05 & $1.050( \pm 0.005)$ & $66.90( \pm 0.10)$ \\
\hline$"$ & 0.10 & $1.030( \pm 0.006)$ & $70.90( \pm 0.08)$ \\
\hline$"$ & 0.20 & $1.000( \pm 0.003)$ & $72.70( \pm 0.07)$ \\
\hline$"$ & 0.30 & $0.970( \pm 0.003)$ & $73.90( \pm 0.09)$ \\
\hline$"$ & 0.40 & $0.940( \pm 0.005)$ & $74.60( \pm 0.10)$ \\
\hline $\mathrm{K}_{2} \mathrm{SO}_{4}$ & 0.05 & $1.060( \pm 0.003)$ & $67.00( \pm 0.09)$ \\
\hline$"$ & 0.10 & $1.040( \pm 0.005)$ & $71.20( \pm 0.08)$ \\
\hline$"$ & 0.20 & $1.010( \pm 0.003)$ & $72.90( \pm 0.05)$ \\
\hline$"$ & 0.30 & $0.980( \pm 0.005)$ & $74.00( \pm 0.10)$ \\
\hline$"$ & 0.40 & $0.950( \pm 0.003)$ & $74.80( \pm 0.05)$ \\
\hline $\mathrm{Na}_{2} \mathrm{SO}_{4}$ & 0.05 & $1.060( \pm 0.003)$ & $67.10( \pm 0.05)$ \\
\hline " & 0.10 & $1.040( \pm 0.003)$ & $71.30( \pm 0.09)$ \\
\hline$"$ & 0.20 & $1.100( \pm 0.003)$ & $73.00( \pm 0.05)$ \\
\hline$"$ & 0.30 & $0.980( \pm 0.003)$ & $74.10( \pm 0.08)$ \\
\hline$"$ & 0.40 & $0.950( \pm 0.003)$ & $74.95( \pm 0.01)$ \\
\hline
\end{tabular}

\section{Effect of type of supporting electrolyte and its concentration on voltammetric response.}

Table 01 gives the peak potentials and peak currents corresponding to the oxidation of $\mathrm{ClO}^{-}$in three different types of supporting electrolytes: $\mathrm{KNO}_{3}, \mathrm{~K}_{2} \mathrm{SO}_{4}$ and $\mathrm{Na}_{2} \mathrm{SO}_{4}$ at five different selected concentrations. No noticeable differences in peak potentials or peak currents were observed for the three different supporting electrolytes. However, with increasing concentration of the supporting electrolyte, a slight increase in peak currents was seen for all 3 electrolytes. The percentage increase in peak current $(\sim 5 \%)$ with increasing concentration from $0.05 \mathrm{~mol} \mathrm{dm}^{-3}$ to $0.10 \mathrm{~mol} \mathrm{dm}^{-3}$ was slightly higher than the percentage increase in current $(\sim 3 \%)$ over the concentration range from $0.1 \mathrm{~mol} \mathrm{dm}^{-3}$ to $0.4 \mathrm{~mol} \mathrm{dm}^{-3}$. For the present work, $\mathrm{KNO}_{3}$ was selected as the supporting electrolyte and $0.10 \mathrm{~mol} \mathrm{dm}^{-3}$ was used as its optimum concentration.

\section{Effect of scan rate of working electrode potential on voltammetric response}

Figure 04 shows the voltammograms obtained for six different scan rates: $10,25,50,100,250$ and $400 \mathrm{mV} \mathrm{s}^{-1}$ of the working electrode potential. The initial and final potentials of $-0.800 \mathrm{~V}$ and $+1.200 \mathrm{~V}$ were used for all scan rates. The peak potential shows a slight drift towards positive direction at low scan rates $\left(10\right.$ to $\left.50 \mathrm{mV} \mathrm{s}^{-1}\right)$. However, the peak potential remained at $+1.040 \mathrm{~V}$ for the rest of the scan rates. The peak current has continued to increase with increasing rates of potential scan. The plot of peak current against the square root of scan rate (Randle Sevcik plot) produced a straight line passing through origin $\left(\mathrm{R}^{2}=0.9993\right)$. In the present study, a complete investigation on the electrochemical reversibility of the reaction was not carried out. The present results indicated that the level of reversibility observed is sufficient for further investigation of the methods for its suitability for analytical applications.

\section{Variation of peak current with variation of $\mathrm{ClO}^{-}$ concentration}

Voltammograms obtained for several different $\mathrm{ClO}^{-}$ concentrations $12.50,25.00,50.00,75.00,100.00$, $150.00,225.00$ and $300.00 \mathrm{mg} \mathrm{dm}^{-3}$ in $0.1 \mathrm{~mol} \mathrm{dm}^{-3}$ $\mathrm{KNO}_{3}$ supporting electrolyte are shown in Figure 05 . The scan rate was $50 \mathrm{mV} \mathrm{s}^{-1}$ and the initial potential and final potential were $+0.600 \mathrm{~V}$ and $+1.200 \mathrm{~V}$. With increase in concentration of $\mathrm{ClO}^{-}$, the peak current had increased. A plot of peak current against the $\mathrm{ClO}^{-}$ concentration had produced a straight line $\left(\mathrm{R}^{2}=0.9996\right)$ passing through origin indicating the analytical utility of the anodic peak current corresponding to the oxidation of $\mathrm{ClO}^{-}$for determination of free chlorine in water. The limit of detection (LOD) was estimated by measuring voltammetric response for 10 aliquots of chlorine free water at the peak potentials. The LOD of $1.0 \mathrm{mg} \mathrm{dm}^{-3}$ was calculated using the slope of the calibration curve and the standard deviation (S.D.) of the blank(s) as follows. 


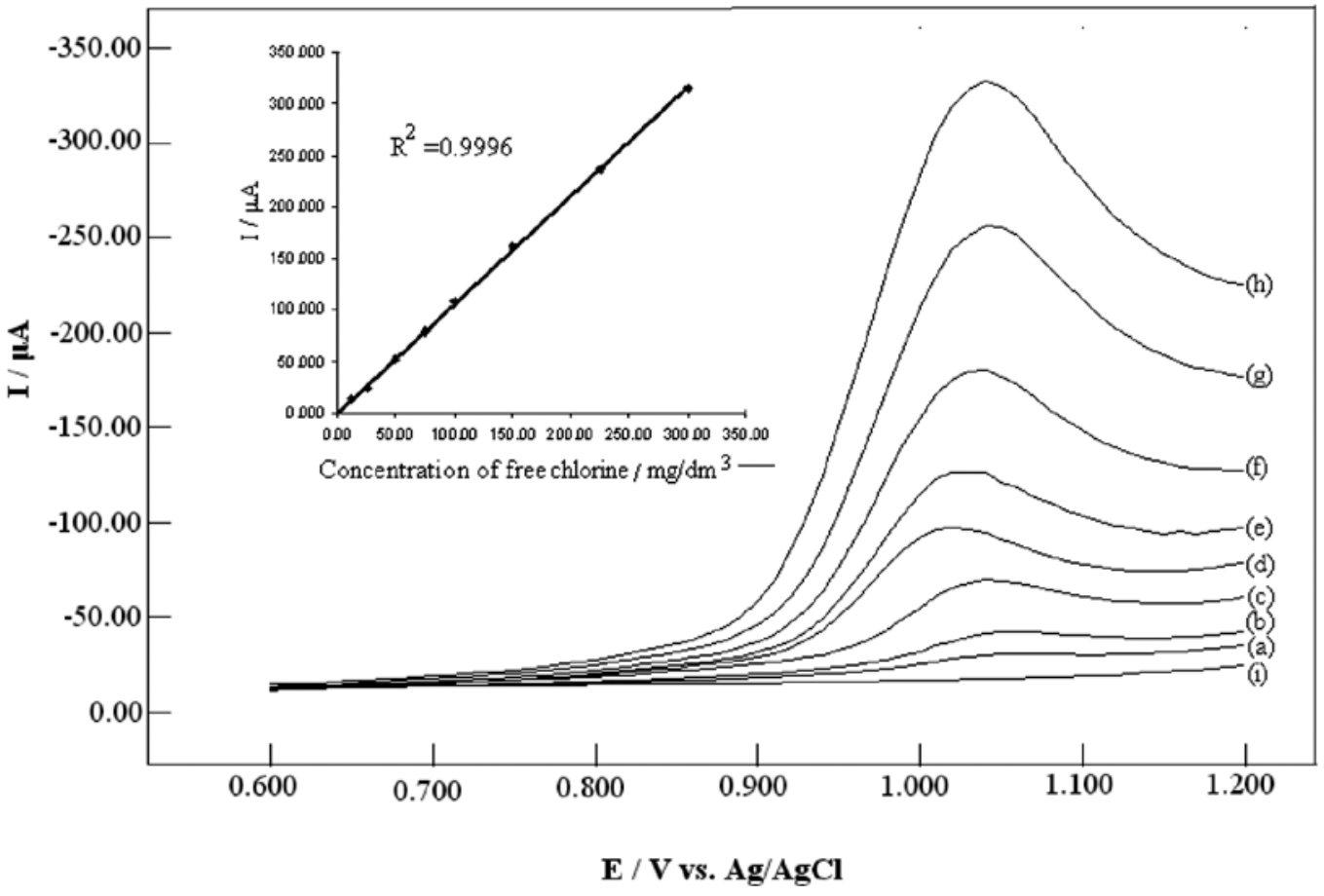

Figure 5: Linear sweep voltammograms for several concentrations of $\mathrm{ClO}^{-}:$(a) $12.50 \mathrm{mg} \mathrm{dm}^{-3}$, (b) $25.00 \mathrm{mg} \mathrm{dm}^{-3}$, (c) 50.00 $\mathrm{mg} \mathrm{dm} \mathrm{m}^{-3}$, (d) $75.00 \mathrm{mg} \mathrm{dm}^{-3}$, (e) $100.00 \mathrm{mg} \mathrm{dm}^{-3}$, (f) $150.00 \mathrm{mg} \mathrm{dm}^{-3}$, (g) $225.00 \mathrm{mg} \mathrm{dm}^{-3}$, (h) $300.00 \mathrm{mg} \mathrm{dm}^{-3}$ (i) blank, in $0.10 \mathrm{~mol} \mathrm{dm}^{-3} \mathrm{KNO}_{3}$ supporting electrolyte at graphite electrode. Initial and final potentials were +0.600 $\mathrm{V}$ and $+1.200 \mathrm{~V}$ respectively. The scan rate was $50 \mathrm{mV} \mathrm{s}^{-1}$. Insert shows a plot of anodic peak current versus the concentration of $\mathrm{ClO}^{-}$

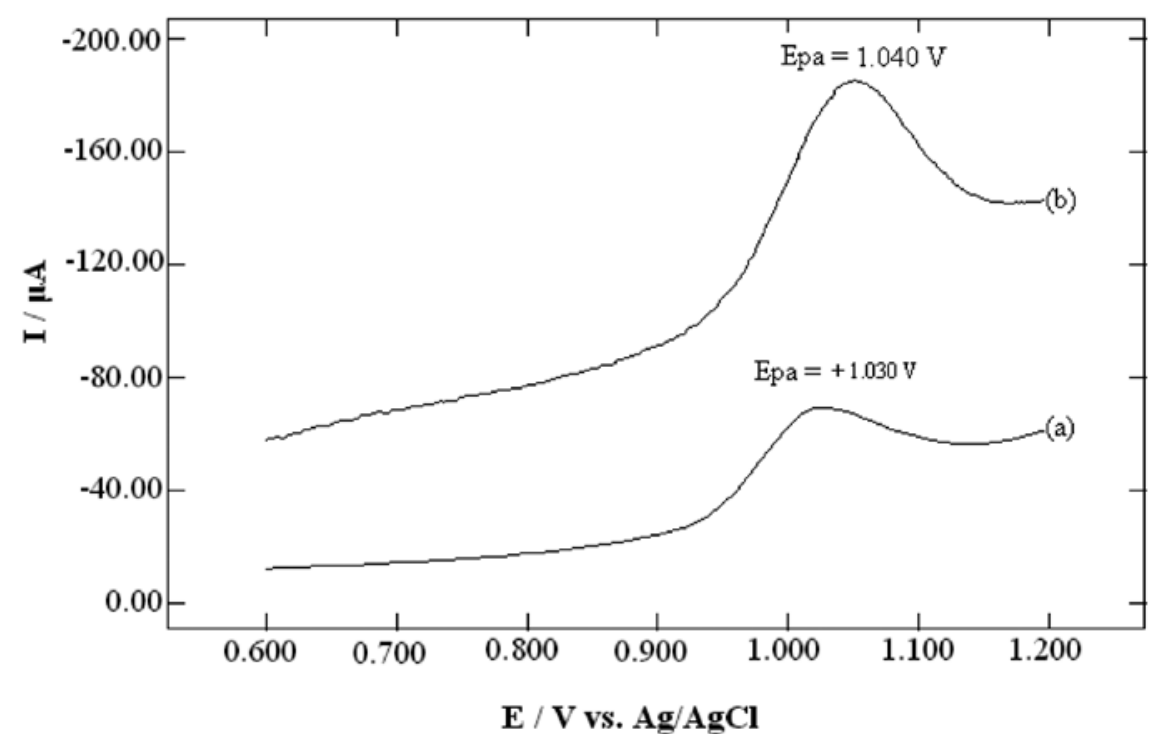

Figure 6: Voltammograms for a $\mathrm{ClO}^{-}$concentration of $50 \mathrm{mg} \mathrm{dm}^{-3}$ in $0.10 \mathrm{~mol} \mathrm{dm}^{-3} \mathrm{KNO}_{3}$ supporting electrolyte with a graphite working electrode (a) linear sweep voltammetry (scan rate of $50 \mathrm{mV} / \mathrm{s}$ ) and (b) square wave voltammetry (frequency of $50 \mathrm{~Hz}$ and pulse height of $50 \mathrm{mV}$ ). Initial and final potentials were $-0.800 \mathrm{~V}$ and $+1.200 \mathrm{~V}$ respectively. 
Table 02: Comparison of the analytical results obtained with the proposed method and the iodometric method, during determinations of $\mathrm{ClO}^{-}$in commercial bleaching solutions at three different concentration levels.

\begin{tabular}{|c|c|c|c|c|c|c|c|c|c|c|}
\hline \multirow{3}{*}{$\begin{array}{l}\text { Sample } \\
\text { label }\end{array}$} & \multicolumn{10}{|c|}{ Concentration of $\mathrm{ClO}^{-} / \mathrm{mg} \mathrm{dm}^{-3}$} \\
\hline & \multicolumn{5}{|c|}{ Linear sweep voltammetric method } & \multicolumn{5}{|c|}{ Iodometric method } \\
\hline & $1 \mathrm{st}$ & $2 \mathrm{nd}$ & $3 \mathrm{rd}$ & Mean & $\begin{array}{l}\text { Standard } \\
\text { deviation }\end{array}$ & $1 \mathrm{st}$ & $2 \mathrm{nd}$ & $3 \mathrm{rd}$ & Mean & $\begin{array}{l}\text { Standard } \\
\text { deviation }\end{array}$ \\
\hline 1 & 420.0 & 418.0 & 416.0 & 418.0 & 2.0 & 416.0 & 412.0 & 420.0 & 416.0 & 4 \\
\hline 2 & 211.5 & 209.2 & 205.5 & 208.7 & 3.0 & 209.2 & 210.4 & 209.5 & 207.7 & 2.5 \\
\hline
\end{tabular}

$$
\text { LOD }=\frac{3 \times \text { S.D. }}{\text { Slope }}
$$

The concentration of $\mathrm{ClO}^{-}$that gives $5 \%$ deviation from nominal sensitivity was used to determine the upper limit of calibration $\left(300 \mathrm{mg} \mathrm{dm}^{-3}\right)$ curve for the present method.

\section{Comparison of performance: linear sweep voltammetry versus square wave voltammetry}

Figure 06 shows a nearly $100 \%$ increase in peak current with square wave voltammetry compared to linear sweep voltammetry for the $50 \mathrm{mg} \mathrm{dm}^{-3}$ free chlorine concentration in $0.10 \mathrm{~mol} \mathrm{dm}^{-3} \mathrm{KNO}_{3}$ supporting electrolyte. The pulse height and frequency for the square wave voltammetry were $50 \mathrm{mV}$ and $50 \mathrm{~Hz}$ respectively. This indicates the possibility of using square wave voltammetry with an improved sensitivity for determination for free chlorine in aqueous environments.

\section{Validation of analytical results and analysis of real sample}

Table 02 gives the results obtained for $\mathrm{CIO}^{-}$contents in a commercially available bleaching solution at three different concentration levels measured in triplicate using the proposed linear sweep voltammetric method and the iodometric method. The percentage differences of the results between voltammetric method and the iodometric method were $0.48 \%, 0.48 \%$ and $1.80 \%$ for the three concentration levels (1, 2 and 3 respectively). In addition, the standard deviations of the results for the voltammetric determination were lower than those for the iodometric method.

\section{CONCLUSION}

Linear sweep voltammetry with a graphite electrode can be used for determination of free chlorine concentrations in the range of $1.0-300.0 \mathrm{mg} \mathrm{dm}^{-3}$ with a high degree of reproducibility. Any of the electrolytes $\mathrm{KNO}_{3}, \mathrm{~K}_{2} \mathrm{SO}_{4}$ and $\mathrm{Na}_{2} \mathrm{SO}_{4}$ at a concentration of $0.1 \mathrm{~mol} \mathrm{dm}^{-3}$ can be used as the supporting electrolyte for the determination. Removal of oxygen, by purging with nitrogen, is not required for the proposed method. Square wave voltammetry in place of linear sweep voltammetry can also be used if necessary to determine concentration of $\mathrm{ClO}^{-}$lower than $1.0 \mathrm{mg} \mathrm{dm}^{-3}$.

\section{References}

1. White G.C. (1986). Handbook of Chlorination, second edition. Van Nostrand, Recinhold, New York.

2. Galal-Gorchev H. (1996). Chlorine in water disinfection. Pure \& Applied Chemistry 68(9): 1731-1735.

3. Fauvarque J. (1996). The Chlorine Industry. Pure \& Applied Chemistry 68(9): 1713-1720.

4. Solomon K.R. (1996). Chlorine in the bleaching of pulp and paper. Pure \& Applied Chemistry 68(9): 1721-1730.

5. Mendham J., Denney R.C., Barnes J.D., Thomas M.J.K., (2004). Vogel's Textbook of Quantitative Chemical Analysis, sixth edition, p.435. Pearson Education, Singapore.

6. Kodera F., Umeda M. \& Yamada A. (2005). Determination of free chlorine based on anodic voltammetry using platinum, gold and glassy carbon electrode. Analytica Chimica Acta 537:293-298.

7. Kodera F., Kishoka S., Umeda M. \& Yamada A. (2004). Electrochemical detection of free chlorine using anodic current. Japanese Journal of Applied Physics 43(7A):L913-L914.

8. Kishoka S., Kosugi T. \& Yamada A. (2004). Electrochemical determination of a free chlorine residual using cathodic potential-step chronocoulometry. Electroanalysis 17(8): 724-726.

9. Tsaousis A.N. \& Huber C.O. (1985). Flow-injection amperometric determination of chlorine at a gold electrode. Analytica Chimica Acta 178:319-323.

10. Skoog D.A., West D.M., Holler F.J. \& Crouch S.R. (2004). Fundamental of Analytical Chemistry, eighth edition p. A 13. Thomoson Asia (pte.) Ltd., Singapore. 